\title{
Analisis Miskonsepsi Matematis: Dampak Strategi Pembelajaran Predict Discuss Explain Observe Discuss Explain
}

\author{
Ernawati ${ }^{*}$, Siska Andriani1, Farida1, Bambang Sri Anggoro1 \\ ${ }^{1}$ Universitas Islam Negeri Raden Intan Lampung. Jalan Endro Suratmin, Sukarame, Bandar Lampung \\ 35133, Indonesia. \\ * Corresponding Author. E-mail: ernawati151296@gmail.com
}

\begin{abstract}
Abstrak
Penelitian ini bertujuan untuk mengatahui pengaruh strategi pembelajaran PDEODE terhadap miskonsepsi peserta didik. Penelitian ini merupakan penelitian kuantitatif jenis Quasi Eksperimen Design dengan menggunakan strategi pembelajaran PDEODE ada 6 tahap dalam pembelajaran ini yaitu 1) Predict 2) Discuss 3) Explain 4) Observe 5) Discuss 6) Explain. Populasi dalam penelitian ini adalah semua siswa kelas VIII di MTs Al-Hikmah Kedaton Bandar Lampung pada tahun ajaran 2019/2020. Sampel dalam penelitian ini adalah kelas VIII D (Kelas Kontrol dengan menggunakan metode konvensional) dan VIII E (Kelas Eksperimen dengan menggunakan strategi pembelajaran PDEODE). Instrumen pengumpulan data yang digunakan yaitu RPP, instrumen tes pilihan ganda yang disertai dengan skala keyakinan yang diberikan kepada ahli materi dan ahli soal untuk mengetahui kelayakan instrumen pembelajaran dan diberikan kepada peserta didik (Pretest dan Posttest). Berdasarkan hasil penelitian pembelajaran matematika menggunakan strategi PDEODE terhadap miskonsepsi peserta didik lebih efektif dari pada pembelajaran matematika yang menggunakan metode konvensional.
\end{abstract}

Kata kunci: Miskonsepsi, Strategi Pembelajaran PDEODE.

\section{Abstract}

This study aims to determine the effect of PDEODE learning strategies on students' misconceptions. This research is a quantitative research type Quasi Design Experiment using PDEODE learning strategies there are 6 stages in this learning namely 1) Predict 2) Discuss 3) Explain 4) Observe 5) Discuss 6) Explain. The population in this study were all students of class VIII at MTs Al-Hikmah Kedaton Bandar Lampung in the 2019/2020 school year. The sample in this study was class VIII D (Control Class using conventional methods) and VIII E (Experiment Class using the PDEODE learning strategy). Data collection instruments used were RPP, multiple choice test instruments accompanied by a scale of confidence given to material experts and question experts to determine the feasibility of the learning instrument and given to students (Pretest and Posttest). Based on the results of mathematics learning research using the PDEODE strategy for students' misconceptions is more effective than mathematics learning using conventional methods.

Keywords: Misconceptions, Learning Strategies PDEODE.

PENDAHULUAN

Pendidikan merupakan proses interaksi yang mendorong terjadinya belajar. Peningkatan sumber daya manusia melalui pendidikan itu sangatlah penting. Dengan adanya belajar terjadilah perkembangan dan mental peserta didik (Dimyati \& Mujiono, 2013). Selain itu pendidikan juga mempunyai kedudukan untuk memperbaiki dan mengangkat derajat manusia yang lebih tinggi. Oleh karena itu, pendidikan harus mendapatkan perhatian lebih oleh pemerintah ataupun masyarakat. Sehingga tujuan dari pendidikan pun akan tercapai. Pendidikan akan menghasilkan manusia berkualitas dalam hal pengetahuan dan 
keterampilan serta memiliki kemampuan berfikir kritis, kreatif, dan sikap terbuka. Pendidikan sains yang berkualitas akan menghasilkan manusia yang memiliki pengetahuan, pemahaman, proses dan sikap sains yang berkualitas (Maulida \& Abdullah, 2013).

Matematika merupakan salah satu mata pelajaran yang diajarkan keberbagai jenjang pendidikan mulai dari kanak-kanak hingga perguruan tinggi, karena pentingnya matematika untuk menyelesaikan permasalahan dalam kehidupan sehari-hari (Putra, 2016). Materi matematika yang dipelajari ini, peserta didik hanya mendapat pengetahuan dan dituntut mampu untuk memperkirakan materi yang belum mampu dibayangkan, sebagian besar pendidik hanya menekankan daya ingat dalam mengetahui kemampuan peserta didik. Dalam memahami konsep matematika tidak semua peserta didik dapat mempunyai tafsiran dan pemahaman yang sama, jadi masalah yang dihadapi dunia pendidikan kita adalah banyak peserta didik yang mengalami miskonsepsi. Sebab pembelajaran yang dilakukan oleh pendidik masih menggunakan pola-pola lama, sehingga hal tersebut dapat mengakibatkan peserta didik banyak yang mengalami misskonsepsi terhadap materi yang disampaikan. Sehingga yang demikian dapat mempengaruhi prestasi belajar peserta didik.

Ketidaksesuaian pemahaman yang sering dialami oleh siswa disebut dengan miskonsepsi atau konsep alternative (Nurul, Samsudin, \& Gina, 2017). Menurut Suparno dalam (Resbiantoro \& Nugraha, 2017; Utami, Agung, \& Bahriah, 2017; Zulvita, Halim, \& Elisa, 2017), miskonsepsi adalah suatu konsep yang tidak sesuai dengan konsep yang diakui oleh para ahli. Berpijak dari permasalahan tersebut, solusi yang diambil untuk mengatasi miskonsepsi yang terjadi adalah pendidik harus mampu menggunakan strategi pembelajaran PDEODE.

Strategi PDEODE pada awalnya disarankan oleh SavanderRanne \& Kolari (2003) dan pertama kali digunakan oleh Kolari Et Al., (2005) di dunia pendidikan (Ardiyan \& Rusimamto, 2015). PDEODE merupakan strategi pembelajaran yang dikembangkan dari strategi pembelajaran POE (Predict-ObserveExplain). POE adalah strategi pembelajaran yang menggunakan pendekatan konstruktivis (Dipalaya, Susilo, \& Corebima, 2016). Kontruktivisme merupakan teori pembelajaran kognitif yang baru dalam psikologi pendidikan yang menyatakan bahwa peserta didik harus menemukan sesuatu untuk dirinya, dan peserta didik harus berkerja memecahkan masalah (Trianto, 2012).

Menurut Costu dalam Lestari dalam (Mas'udah, Surahmat, \& Nursit, 2019) menyatakan bahwa strategi pembelajaran PDEODE memfasilitasi siswa untuk membuat siswa memahami peristiwa yang terjadi sehari-hari atau membantu siswa menerima pemahaman konsep yang lebih baik. PDEODE memiliki enam tahapan, yaitu tahap prediction, tahap discuss, tahap explain, tahap observe, tahap discuss, tahap explain (Dewi, Suhandi, \& Indonesia, 2016).

Berdasarkan penelitian terdahulu oleh (Maulida \& Abdullah, 2013; Ngurah, Laksana, Studi, Guru, \& Dasar, 2016; Resbiantoro \& Nugraha, 2017; 
Suniati, Sadia, \& Suhandana, 2013; Yuliati, 2017) strategi pembelajaran mampu mengatasi miskonsepsi pada mata pelajaran IPA tingkat SD dan SMP, Sedangkan jika tingkat SMA, miskonsepsi terjadi pada mata pelajaran biologi (Lyanda Fitriani Chaniarosi, 2014), fisika (Fauziah, Yanthi, \& Yuniarti, 2016; Maulana, 2010; Subijakto, 2015; Zulvita et al., 2017) dan kimia (Noviani \& Istiyadji, 2017; Nurul et al., 2017; Pratiwi \& Wasis, 2013; Rahayu \& Nasrudin, 2014). Persamaan dalam penelitian ini adalah sama-sama meneliti miskonsepsi dalam dunia pendidikan. Adapun keterbaruannya adalah penelitian ini dilakukan untuk mengetahui pengaruh strategi pembelajaran PDEODE terhadap miskonsepsi peserta didik pada mata pelajaran matematika.

Penelitian selanjutnya, strategi pembelajaran PDEODE digunakan untuk meningkatkan keterampilan komunikasi (Dipalaya et al., 2016), pemahaman konsep (Dewi et al., 2016; Kusnadi, Hamdiyati, \& Azkya, 2018; Mas'udah et al., 2019) dan berpikir kritis (Suartini, Kusmariyatni, \& Japa, 2016) dalam proses pembelajaran. Persamaan dalam penelitian ini adalah sama-sama menggunakan strategi PDEODE dalam proses pembelajaran. Adapun keterbaruan dari penelitian ini yaitu peneliti ingin mengetahui miskonsepsi peserta didik.

\section{METODE PENELITIAN}

Metode yang digunakan dalam penelitian ini adalah metode penelitian Quasi Eksperiment Design karena penelitian ini mempunyai kelompok kontrol, tetapi kelompok kontrol hanya mengontrol variabel-variabel luar yang mempengaruhi pelaksanaan kegiatan eksperimen. Desain Kuasi eksperimen yang digunakan adalah Nonequivalent Control Group Design. Pada Desain ini hampir sama dengan pretest-postest control group design, hanya pada desain kelompok eksperimen maupun kelompok kontrol tidak dipilih secara random (Sanjaya, 2013).

Penelitian ini terdapat dua kelas, yaitu kelompok eksperimen dan kelompok kontrol yang bersifat homogen. Sebelum dilakukan perlakuan diberikan pretest untuk mengetahui keadaan awal adakah perbedaan antara kelas eksperimen dan kelas kontrol serta diberikan postest yang sama. Kelas eksperimen diberikan perlakuan dengan menggunakan strategi PDEODE ( Predict Discuss Explain Observe Discuss Explain), sedangkan kelas kontrol menggunakan metode konvensional. Selanjutnya diberikan tes akhir setelah kedua objek diberi perlakuan

Teknik pengambilan sampel dalam penelitian ini menggunakan teknik acak kelas. Variabel yang digunakan dalam penelitian ini adalah variabel bebas dan variabel terikat, yaitu: Variabel bebas adalah variabel yang cenderung mempengaruhi variabel terikat. Variabel bebas dalam penelitian ini adalah Strategi pembelajaran PDEODE (X). Sedangkan variabel terikat adalah variabel yang dipengaruhi oleh variabel bebas. Variabel terikat dalam penelitian ini adalah terhadap miskonsepsi peserta $\operatorname{didik}(\mathrm{Y})$.

Teknik pengumpulan data pada penelitian eksperimen semu ini dengan menggunakan cara wawancara, tes dan dukementasi. Selanjutnya, penelitian ini menggunakan instrumen-instrumen seperti silabus kelas eksperimen dan 
kelas control, Rencana Pelaksanaan Pembelajaran (RPP), LKS (Lembar Kerja Siswa) dan tes.

Uji coba instrumen pada penelitian ini dilakukan di MTs Al-Hikmah Bandar Lampung tahun ajaran 2019/2020. Instrumen dalam penelitian ini adalah tes pilihan ganda disertai skala keyakinan terhadap miskonsepsi peserta didik. Sebelum instrumen penelitian digunakan maka dilakukan penelaahan dan analisis hasil uji coba instrumen. Uji coba instrumen dilakukan pada 30 peserta didik kelas IX A

Instrumen dalam penelitian ini menggunakan tes obyektif berbentuk pilihan ganda (Multiple Choice), validitas dapat dihitung dengan koefisien menggunakan product moment dengan rumus (Arikunto, 2012):

$r_{x y}=\frac{\mathrm{N} \sum \mathrm{XY}-\left(\sum \mathrm{X}\right)\left(\sum \mathrm{Y}\right)}{\sqrt{\left\{\mathrm{N} \sum \mathrm{X}^{2}-\left(\sum \mathrm{X}\right)^{2}\right\}\left\{\mathrm{N} \sum \mathrm{Y}^{2}-\left(\sum \mathrm{Y}\right)^{2}\right\}}}$

Keterangan:

$\mathrm{r}_{\mathrm{xy}}=$ Koefisien korelasi suatu butir

$\mathrm{x}=$ Skor butir soal

$\mathrm{y}=$ Skor total

$\mathrm{n}=$ Banyak subjek (teste)

Teknik analisis data merupakan langkah yang sangat penting dalam kegiatan penelitian, analisis data yang benar dan tepat akan menghasilkan kesimpulan yang benar. Analisis data yang dilakukan dalam penelitian ini adalah uji prasyarat analisis, uji normalitas, uji homogenitas, dan uji hipotesis.

\section{HASIL DAN PEMBAHASAN}

1. Uji Validitas Soal

Hasil analisis uji validitas butir soal dari 25 item soal pilihan ganda yang telah diujicobakan, dengan nilai $\mathrm{r}_{-}$Tabel $=r(0,05 ; 25-2)=0,360$ diperoleh 20 item soal yang dinyatakan valid. Hal ini menunjukkan bahwa dari 25 item soal yang telah diujikan tersebut layak untuk digunakan untuk pengambilan data miskonsepsi pada penelitian ini.

2. Uji Reliabilitas Soal

Berdasarkan hasil perhitungan uji reliabilitas 25 butir soal uji coba tes miskonsepsi diperoleh nilai $\mathrm{r}_{11}=0,723$ Kemudian nilai $\mathrm{r}_{11}$ dibandingkan dengan nilai $\mathrm{r}_{\text {Tabel }}=\mathrm{r}(0,05 ; 25-2)=0,360$. Berdasarkan hasil data tersebut dapat disimpulkan bahwa $\mathrm{r}_{11} \geq \mathrm{r}$ Tabel, instrumen tersebut dinyatakan reliabel dengan kategori tinggi. Semakin tinggi koefisien reliabilitas suatu soal, semakin tinggi ketepatannya, sehingga instrumen soal layak untuk digunakan dalam pengambilan data miskonsepsi.

3. Uji Tingkat Kesukaran Soal

Hasil analisis uji tingkat kesukaran butir soal menunjukkan bahwa tingkat kesukaran dari 25 item soal yang diujicobakan diperoleh 5 butir soal yang tergolong kriteria sukar $(0,00<\mathrm{P}<0,30$ ) yaitu no $3,8,14,22,25$ selebihnya tergolong sedang $(0,31<\mathrm{P} \leq 0,70)$ yaitu nomor $1,2,4,5,6,7,9,10,11,12,13,15$, 16, 17, 18, 19, 20, 21, 23, 24.

4. Uji Daya Pembeda Soal

Hasil perhitungan uji daya pembeda 25 item soal yang telah diujicobakan diperoleh 5 soal, 13 soal yang memiliki kriteria cukup, 4 soal yang memiliki kriteria baik, 3 soal yang memiliki kriteria false dan 0 soal yang memiliki kriteria baik sekali. Artinya item soal tersebut sudah sangat cukup membedakan kemampuan peserta didik tau konsep, tidak tau konsep dan miskonsepsi.

5. Deskripsi Data Amatan

Penelitian ini dilakukan dengan tujuan untuk mengetahui pengaruh strategi pembelajaran PDEODE (Predict Discuss Explain Observe Discuss Explain) terhadap miskonsepsi peserta didik. Peneliti melakukan 5 kali pertemuan dengan 3 kali proses pembelajaran dan 2 kali pretest dan posttest. Berdasarkan 
Desimal, 2 (3), 2019 - 263

Ernawati, Siska Andriani, Farida, Bambang Sri Anggoro

penelitian yang telah dilakukan didapatkan hasil sebagai berikut:

a. Data persentase pretest dan posttest berdasarkan kategori tingkat pemahaman peserta didik kelas eksperimen
Hasil analisis jawaban pada kelas eksperimen peserta didik VIII E dari tes pilihan ganda disertai dengan tingkat keyakinan pada materi sistem persamaan linier dua variabel ditunjukkan pada Tabel 1

Tabel 1. Rekapitulasi Jumlah Peserta Didik Kelas Eksperimen yang Tahu Konsep (TK), Tidak Tahu Konsep (TTK) dan mengalami Miskonsepsi (M)

\begin{tabular}{|c|c|c|c|c|c|}
\hline \multicolumn{3}{|c|}{ Pretest } & \multicolumn{3}{|c|}{ Posttest } \\
\hline TK & TTK & M & TK & TTK & M \\
\hline $29,71 \%$ & $14,14 \%$ & $60,14 \%$ & $84,28 \%$ & $6,05 \%$ & $9,57 \%$ \\
\hline
\end{tabular}

Berdasarkan Tabel 1 diatas, persentase pretest dan posttest tingkat pemahaman peserta didik pada materi sistem persamaan linier dua variabel pada kelas eksperimen. Pada kategori "Miskonsepsi" dengan rata-rata persentase pretest sebesar 60,14\% namun pada posttest miskonsepsi yang dialami peserta didik sebesar 9,57\% dan pada kategori tingkat pemahaman peserta didik yang paling terendah terletak pada kategori "Tidak Tahu Konsep" dengan rata-rata persentase pretest $14,14 \%$ dan persentase posttest sebesar $6,05 \%$. Sedangkan persentase rata-rata pemahaman peserta didik pada kategori "Tahu Konsep" pada pretest sebesar 29,71\% dan posttest sebesar $84,28 \%$.

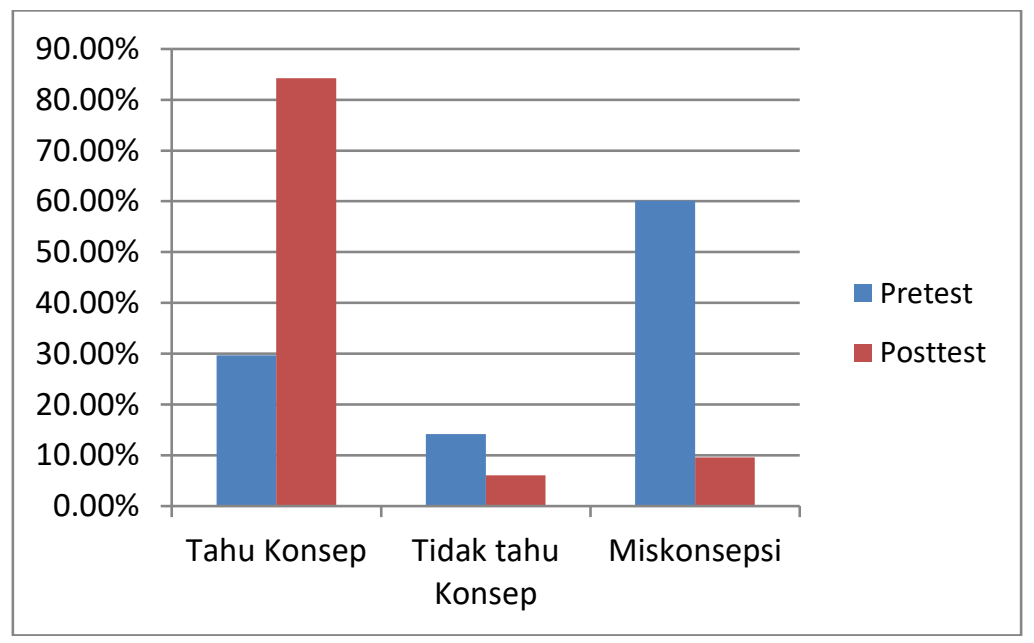

Gambar 1. Rekapitulasi Nilai Pretest dan Postest pada Kelas Eksperimen

Berdasarkan Gambar 1, memperlihatkan hasil pretest dan posttest pada kategori miskonsepsi pada kelas kontrol sebesar $60,14 \%$ menjadi $9,57 \%$ sehingga miskonsepsi yang dialami peserta didik menurun.

b. Data persentase pretest dan posttest berdasarkan kategori tingkat pemahaman peserta didik kelas kontrol

Hasil analisis jawaban pada kelas kontrol peserta didik VIII D dari tes pilihan ganda disertai dengan tingkat keyakinan pada materi sistem persamaan linier dua variabel ditunjukkan pada Tabel 2 .

Tabel 2. Rekapitulasi Jumlah Peserta Didik Kelas Kontrol yang Tahu Konsep (TK), Tidak Tahu Konsep (TTK) dan Mengalami Miskonsepsi (M) 
Desimal, 2 (3), 2019 - 264

Ernawati, Siska Andriani, Farida, Bambang Sri Anggoro

\begin{tabular}{lccccc}
\hline \multicolumn{5}{c}{ Jumlah Persentase Rata-rata Kelas Kontrol } \\
TK & Pretest & & Posttest \\
$26,71 \%$ & $16,57 \%$ & $58,14 \%$ & $68,14 \%$ & $13,42 \%$ & $19,71 \%$ \\
\hline
\end{tabular}

Berdasarkan Tabel 2, persentase pretest dan posttest tingkat pemahaman peserta didik pada materi sistem persamaan linier dua variabel pada kelas kontrol. Pada kategori "Miskonsepsi" dengan rata-rata persentase pretest sebesar 58,14\% namun pada posttest miskonsepsi yang dialami peserta didik sebesar 19,71\% dan pada kategori tingkat pemahaman peserta didik yang paling terendah terletak pada kategori "Tidak Tahu Konsep" dengan rata-rata persentase pretest 16,57\% dan persentase posttest sebesar 13,42\%. Sedangkan persentase rata-rata pemahaman peserta didik pada kategori "Tahu Konsep" pada pretest sebesar $26,71 \%$ dan posttest sebesar $68,14 \%$.

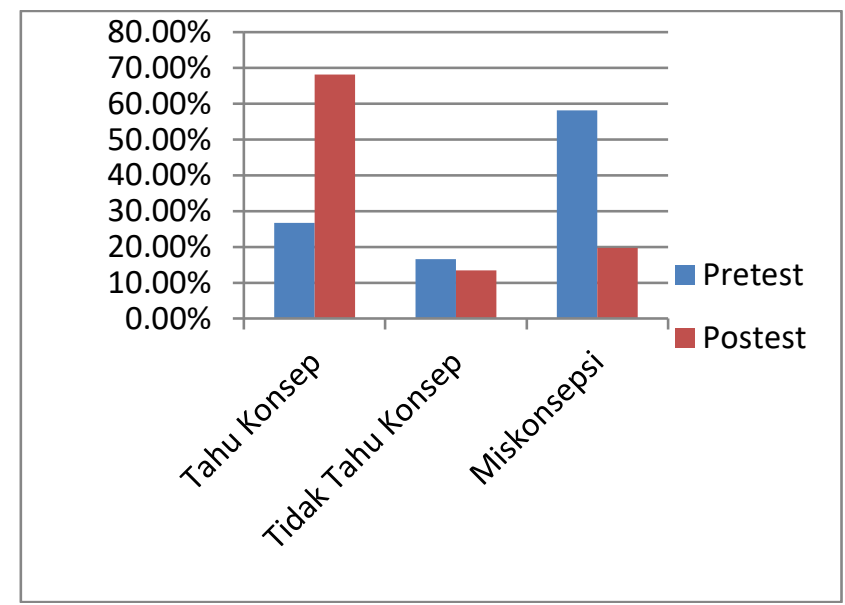

Gambar 2. Rekapitulasi Nilai Pretest dan Postest pada Kelas Kontrol

Berdasarkan Gambar 2 memperlihatkan hasil pretest dan posttest pada kategori miskonsepsi pada kelas kontrol sebesar 58,14\% menjadi $19,71 \%$ sehingga miskonsepsi yang dialami peserta didik menurun. Berbeda dengan eksperimen, miskonsepsi pada pretest kelas eksperimen lebih besar jika dibandingkan kelas kontrol, namun hasil posttest menunjukkan persentase miskonsepsi yang dialami peserta didik pada kelas eksperimen menurun pesat dibandingkan dengan kelas kontrol.

6. Uji Prasyarat Analisis

a. Uji Normalitas

Uji normalitas dilakukan untuk mengetahui data berdistribusi normal atau tidak. Uji normalitas yang digunakan adalah dengan menggunakan metode kolmogorov-Smirnov pada program SPSS dengan taraf signifikan 5\%. Hasil uji normalitas untuk data pretest dan posttest pada kelas eksperimen dan kelas kontrol dapat dilihat pada Tabel 3.

Tabel 3. Uji Normalitas Pretest dan

Posttest Kelas Eksperimen dan Kelas Kontrol

\begin{tabular}{ccc}
\hline Statistik & Eksperimen & Kontrol \\
Sig. & 0,991 & 0,971 \\
Uji & & \\
Kolmogorov- & Sig. $\geq 0,05$ & Sig $\geq 0,05$ \\
Smirnov & & \\
Kesimpulan & Normal & Normal \\
\hline
\end{tabular}

Berdasarkan Tabel 3, terlihat bahwa kedua data berdistribusi normal. Nilai Sig. data untuk kelas eksperimen sebesar $0,991>0,05$. Nilai Sig. untuk data kelas kontrol sebesar $0,971>0,05$. Jadi dapat disimpulkan bahwa kelas eksperimen yang menggunakan strategi PDEODE (Predict Discuss Explain Observe Discuss Explain) dan kelas kontrol yang menggunakan model konvensioanal merupakan sampel yang berasal dari populasi yang berdistribusi normal.

b. Uji Homogenitas

Uji homogenitas data pada penelitian dilakukan untuk mengetahui apakah kelas eksperimen dan kelas kontrol memiliki varians yang sama atau tidak. Pada penelitian ini menggunakan Uji Homogeneity of variances. Hasil analisis data uji homogenitas kelas 
eksperimen dan kelas kontrol dapat dilihat pada Tabel 4.

Tabel 4. Uji Homogenitas Posttest

\begin{tabular}{cc}
\hline Statistik & $\begin{array}{c}\text { Postest Kelas } \\
\text { Eksperimen dan } \\
\text { Kelas Kontrol }\end{array}$ \\
$\begin{array}{c}\text { Sig. } \\
\text { Uji Homogenity of } \\
\text { variance } \\
\text { Kesimpulan }\end{array}$ & 0,772 \\
Sig. $\geq 0,05$ \\
Homogen \\
\hline
\end{tabular}

Berdasarkan Tabel 4, terlihat bahwa nilai Sig. pada posttest kelas eksperimen dan kelas control sebesar 0,772 yang artinya $0,772>0,05$. Sesuai dengan kriteria uji, jika nilai Sig. $\geq 0,05$ maka data sampel mempunyai varians yang homogen. Perolehan nilai ini menunjukkan bahwa kelas eksperimen dan kelas kontrol berasal dari populasi homogen.

c. Uji Hipotesis

Setelah dilakukan uji normalitas dan homogenitas maka dilakukan analisis data untuk menguji hipotesis yang telah diajukan, uji ini dilakukan untuk mengetahui ada tidaknya perbedaan yag signifikan antara peserta didik yang diberikan perlakuan dengan Strategi Pembelajaran PDEODE (Predict Discuss Explain Observe Discuss Explain) dengan peserta didik yang diberikan perlakuan menggunakan model pembelajaran konvensional. Hasil uji hipotesis data menggunakan Independent-Sample $T$ Test dapat dilihat pada Tabel 5.

Tabel 5. Hasil Uji Hipotesis Kelas Eksperimendan Kontrol

\begin{tabular}{cc}
\hline Uji Hipotesis & Kelas Eksperimen dan \\
Independent & Kelas Kontrol \\
Sample T Test & \\
Kriteria & Sig.(2-tailed) $\leq 0,05$ \\
Sig.(2-tailed) & 0,00 \\
Keputusan & $\mathrm{H}_{1}$ diterima \\
\hline
\end{tabular}

Berdasarkan Tabel 5, terlihat bahwa untuk data kelas Eksperimen dan kelas kontroldiperoleh nilai Sig. (2-tailed) sebesar 0,00. Nilai Sig.(2-tailed) $<0,05$, artinya $\mathrm{H}_{1}$ diterima. Dengan demikian dapat disimpulkan bahwa adanya perbedaan Strategi Pembelajaran PDEODE dan Pembelajaran Konvesional miskonsepsi peserta didik pada materi system persamaan linier dua variabel kelas VIII MTs Al-Hikmah Kedaton Bandar Lampung.

Hasil analisis data pretest dan posttest pada kedua kelompok menunjukkan bahwa miskonsepsi yang dialami peserta didik dapat dikatakan merata seperti Tabel 1 dan Tabel 2 yang ditunjukkan melalui hasil uji normalitas nilai pretest dan posttest kedua kelompok. Sehingga untuk menguji ada tidaknya perbedaan besarnya miskonsepsi antara kelas eksperimen dengan kelas kontrol maka uji statistik yang digunakan adalah uji parametrik yaitu uji-t. Penggunaan strategi pembelajaran PDEODE, terhadap miskonsepsi peserta didik. Hasil uji-t dengan taraf signifikan menunjukkan bahwa nilai Sig.(2tailed) sebesar 0,00. Nilai Sig.(2-tailed) $<0,05$, artinya $0,00 \leq$ 0,05 sehingga diperoleh kesimpulan bahwa miskonsepsi kelas eksperimen dapat menurun lebih besar daripada kelas kontrol. Kesimpulan ini menunjukkan bahwa adanya perbedaan Strategi pembelajaran PDEODE dan model pembelajaran konvesional dalam terhadap miskonsepsi peserta didik.

Berdasarkan hasil interpresentasi dari pengelolaan pembelajaran menunjukkan bahwa terdapat pengaruh Strategi Pembelajaran PDEODE (Predict Discuss Explain Observe Discuss Explain) terhadap miskonsepsi pada peserta didik, dibandingkan dengan model pembelajaran konvesional. Hal ini disebabkan karena pada strategi pembelajaran PDEODE ( Predict Discuss Explain Observe Discuss Explain) terdapat tahapan - tahapan yang dapat membantu peserta didik menjadi lebih aktif dalam kegiatan belajar mengajar, peserta didik juga dapat menghubungkan antara pengetahuan lama yang telah dimiliki yang biasanya dengan pengetahuan baru yang telah diperoleh dari pengamatan 
yang dilakukan peserta didik. Hal ini didukung dengan hasil penelitian bahwa strategi pembelajaran PDEODE (Predict Discuss Explain Observe Discuss Explain) menekankan peserta didik untuk berperan aktif dalam proses pembelajaran dimana peserta didik menemukan dan membangun pengetahuan mereka sendiri.

Hasil penelitian lain menunjukkan bahwa pembelajaran dengan penerapan strategi pembelajaran PDEODE dapat membantu peserta didik mengembangkan keterampilan proses dalam pembelajaran IPA(Fauziah et al., 2016). Hasil lainnya menunjukkan bahwa strategi pembelajaran PDEODE berpengaruh positif terhadap hasil belajar siswa(Ardiyan \& Rusimamto, 2015). Hal yang serupa dari hasil penelitian mengatakan bahwa penggunaan strategi PDEODE mampu meningkatkan pemahaman konsep dan mereduksi konsepsinya sehingga sesuai dengan konsep ilmiah sebelumnya(Dewi et al., 2016). Perbedaan dengan penelitian ini terletak pada variabelnya, yang terfokus pada miskonsepsi peserta didik. Hal ini berarti penelitian yang dilakukan oleh peneliti sesuai dengan penelitian sebelumnya.

Strategi pembelajaran PDEODE sangat baik digunakan dalam proses pembelajaran Matematika kelas VIII khususnya untuk materi SPLDV (Sistem Persamaan Linier Dua Variabel) mengingat dalam pelaksanaannya peserta didik dapat terlibat langsung dalam proses pembelajaran dengan memberikan pendapat, kritik, penguatan ataupun sanggahan pada saat kegiatan diskusi/presentasi berlangsung. Dengan begitu secara tidak langsung peserta didik dapat memahami materi pelajaran sehingga miskonsepsi yang dialami siswa dapat diperbaiki, karena peserta didik tidak sekedar mengetahui informasi atau pelajaran dari penjelasan guru di dalam kelas, akan tetapi peserta didik langsung menggali pemahaman dengan aktif mencari dan menemukan sendiri konsep-konsep materi yang diajarkan. Dalam hal ini peserta didik mendapatkan lembar kegiatan siswa yang digunakan untuk memahami materi yang ada dengan kegiatan perkelompok.

Berdasarkan uraian yang telah diaparkan sebelumnya, dapat disimpulkan bahwa Penggunaan Strategi pembelajaran PDEODE lebih efektifterhadap miskonsepsi peserta didik kelas VIII pada materi SPLDV (Sistem Persamaan Linier Dua Variabel) di MTs Al-Hikmah Kedaton Bandar Lampung.

\section{SIMPULAN DAN SARAN}

Strategi pembelajaran PDEODE sangat baik digunakan dalam proses pembelajaran Matematika kelas VIII khususnya untuk materi SPLDV (Sistem Persamaan Linier Dua Variabel), mengingat dalam pelaksanaannya peserta didik dapat terlibat langsung dalam proses pembelajaran dengan memberikan pendapat, kritik, penguatan ataupun sanggahan pada saat kegiatan diskusi/presentasi berlangsung. Dengan begitu secara tidak langsung peserta didik dapat memahami materi pelajaran sehingga miskonsepsi yang dialami siswa dapat diperbaiki, karena peserta didik tidak sekedar mengetahui informasi atau pelajaran dari penjelasan guru di dalam kelas, akan tetapi peserta didik langsung menggali pemahaman dengan aktif mencari dan menemukan sendiri konsep-konsep materi yang diajarkan. Dalam hal ini peserta didik mendapatkan lembar kegiatan siswa yang digunakan untuk memahami materi yang ada dengan kegiatan perkelompok. Berdasarkan hasil analisis dan pembahasan terhadap data penelitian yang dilakukan mulai dari tahap perencanaan, pelaksanaan, hingga tahap analisis data dan uji hipotesis maka peneliti menyimpulkan bahwa hasil penelitian pembelajaran matematika menggunakan strategi PDEODE terhadap miskonsepsi peserta didik lebih efektif 
Desimal, 2 (3), 2019 - 267

Ernawati, Siska Andriani, Farida, Bambang Sri Anggoro

dari pada pembelajaran matematika yang menggunakan metode konvensional.

Berdasarkan hasil pengamatan selama proses pembelajaran berlangsung dan juga analisis terhadap hasil belajar matematika peserta didik, maka peneliti memberikan saran untuk peserta didik diharapkan selama proses pembelajaran berlangsung agar lebih aktif dan memanfaatkan pengetahuan yang dimilikinya, dan mengungkapkan pendapatnya dan lebih meningkatkan semangat belajarnya agar mendapatkan hasil yang maksimal. Pendidik sebaiknya dapat menerapkan model pembelajaran yang harus disesuaikan dengan materi yang akan disampaikan agar kemampuan dan kompetensi siswa dapat tercapai dengan baik, dan strategi pembelajaran PDEODE dapat dijadikan salah satu alternatif dalam kegiatan pembelajaran sains lainnya. Bagi penelitian selanjutnya, ada beberapa hal yang harus diperbaiki dalam penggunaan model pembelajaran PDEODE, terutama dalam hal alokasi waktu, fasilitas pendukung termasuk media yang akan digunakan.

\section{DAFTAR PUSTAKA}

Ardiyan, F. Rahmat, \& Rusimamto, P. W. (2015). Pengaruh Strategi Pembelajaran PDEODE (PredictDiscuss - Explain- Observe Discuss - Explain) Terhadap Hasil Belajar Siswa Kelas X Pada Kompetensi Dasar Menerapkan Macam-Macam Gerbang Dasar Rangkaian Logika Di Smk Negeri 2 Surabaya. Jurnal Pendidikan Teknik Elektro, 04(03), 681-686.

Arikunto, S. (2012). Dasar-Dasar Evaluasi Pendidikan Edisi 2. Jakarta: Bumi Aksara.

Dewi, S. Z., Suhandi, A., \& Indonesia, U. P. (2016). Penerapan Strategi Predict, Discuss, Explain, Observe, Discuss, Explain (PDEODE) Pada Pembelajaran Ipa Sd Untuk Meningkatkan Pemahaman Konsep Dan Menurunkan Kuantitas Siswa Yang Miskonsepsi Pada Materi Perubahan Wujud Benda Di Kelas
V. Eduhumaniora: Jurnal Pendidikan Dasar, 8(1), 12-21. Dimyati, \& Mujiono. (2013). Belajar Dan Pembelajaran. Jakarta: Pt Renika Cipta.

Dipalaya, T., Susilo, H., \& Corebima, A. D. (2016). Pengaruh Strategi Pembelajaran PDEODE (PredictDiscuss-Explain-Observe-Discuss-

Explain) Pada Kemampuan Akademik Berbeda Terhadap Keterampilan Komunikasi Siswa. Jurnal Pendidikan: Teori, Penelitian, Dan Pengembangan, 1(9), 17131720.

Fauziah, N. H., Yanthi, N., \& Yuniarti, Y. (2016). Peningkatan Keterampilan Proses Sains Melalui Penerapan Strategi Predict Discuss Explain Observe Discuss Explain. Jurnal Pgsd Kampus Cibiru, 4(4).

Kusnadi, Hamdiyati, Y., \& Azkya, A. (2018). Penerapan Model Belajar PDEODE (Predict-Discuss-ExplainObserve-Discuss-Explain) Untuk Meningkatkan Penguasaan Konsep Siswa Sma Pada Materi Pencemaran Lingkungan. Bioeduin : Jurnal Program Studi Pendidikan Biologi, 8(2), 1-5.

Lyanda Fitriani Chaniarosi. (2014). Identifikasi Miskonsepsi Guru Biologi Sma Kelas Xi Ipa Pada Konsep Sistem Reproduksi Manusia. Jurnal Edubio Tropika, 2(1998), 187-191.

Mas'udah, U., Surahmat, \& Nursit, I. (2019). Pemahaman Konsep Matematika Siswa Menggunakan Model Pembelajaran PDEODE (Predict, Discuss, Explain, Observe, Discuss, Explain) Pada Materi Pola Bilangan Kelas Viii Mts Al-Ihsan. Jp3, 14(2), 291-299.

Maulana, P. (2010). Usaha Mengurangi Terjadinya Miskonsepsi Fisika Melalui Pembelajaran Dengan Pendekatan Konflik Kognitif. Jurnal Pendidikan Fisika Indonesia, 6, 98103.

Maulida, E. L., \& Abdullah, A. A. (2013). 
Desimal, 2 (3), 2019 - 268

Ernawati, Siska Andriani, Farida, Bambang Sri Anggoro

Pengaruh Pendekatan Konflik Kognitif Dengan Metode Demonstrasi Terhadap Miskonsepsi Siswa Ditinjau Dari Hasil Belajar Dalam Bahasan Pemantulan Cahaya Pada Cermin Di Kelas Viii Smp Negeri 2 Buduran Sidoarjo. Jurnal Inovasi Pendidikan Fisika, 02 (03), 126-130.

Ngurah, D., Laksana, L., Studi, P., Guru, P., \& Dasar, S. (2016). Miskonsepsi Dalam Materi Ipa Sekolah Dasar. Jurnal Pendidikan Indonesia, 5(2), 166-175.

Noviani, M. W., \& Istiyadji, M. (2017). Miskonsepsi Ditinjau Dari Penguasaan Pengetahuan Prasyarat Untuk Materi Ikatan Kimia Pada Kelas X. Quantum, Jurnal Inovasi Pendidikan Sains, 8(1), 63-77.

Nurul, F., Samsudin, A., \& Gina, M. (2017). Identifikasi Miskonsepsi Dan Penyebab Miskonsepsi Siswa Menggunakan Four-Tier Diagnostic Test Pada Sub- Materi Fluida Dinamik: Azas Kontinuitas. Jpppf Jurnal Penelitian \& Pengembangan Pendidikan Fisika, 3(2), 175-180.

Pratiwi, A., \& Wasis. (2013). Pembelajaran Dengan Praktikum Sederhana Untuk Mereduksi Miskonsepsi Siswa Pada Materi Fluida Statis Di Kelas Xi Sma Negeri 2 Tuban. Jurnal Inovasi Pendidikan Fisika, 02(03), 117-120.

Putra, F. G. (2016). Pengaruh Model Pembelajaran Reflektif Dengan Pendekatan Matematika Realistik Bernuansa Keislaman Terhadap Kemampuan Komunikasi Matematis. Al-Jabar: Jurnal Pendidikan Matematika, 7(2), 203210.

Rahayu, A. D. P., \& Nasrudin, H. (2014). Penerapan Strategi Konstruktivis Untuk Mereduksi Miskonsepsi Level Sub-Mikroskopik Siswa Pada Materi Kesetimbangan Kimia Kelas Xi Sma Hang Tuah 2 Sidoarjo. Unesa Journal of Chemical Education,
3(02), 88-98.

Resbiantoro, G., \& Nugraha, A. W. (2017). Miskonsepsi Mahasiswa Pada Konsep Dasar Gaya Dan Gerak Untuk Sekolah Dasar. Jurnal Pendidikan Sains (Jps), 5(2), 80-87. Sanjaya, W. (2013). Penelitian Pendidikan Jenis, Metode Dan Prosedur. Jakarta: Pramedia Group.

Suartini, L., Kusmariyatni, N., \& Japa, I. G. N. (2016). Pengaruh Model Pembelajaran Predict-DiscussExplain- Obsereve-Discuss-Explain Berorientasi Masalah Terbuka Terhadap Keterampilan Berpikir Kritis Dalam Mata Pelajaran Ipa. EJournal Pgsd Universitas Pendidikan Ganesha, 4(1), 1-11.

Subijakto, F. (2015). Pengaruh Strategi Pembelajaran Konstruktivisme Dengan Pendekatan Konflik Kognitif Dan Miskonsepsi Fisika Siswa Terhadap Hasil Belajar Fisika. Prosiding Seminar Nasional Fisika (E-Journal) Snf2015, Iv, 117122.

Suniati, N. M. S., Sadia, W., \& Suhandana, A. (2013). Pengaruh Implementasi Pembelajaran Kontekstual Berbantuan Multimedia Interaktif Tehadap Penurunan Miskonsepsi (Studi Kuasi Eksperimen Dalam Pembelajaran Cahaya Dan Alat Optik Di Smp Negeri 2 Amlapura). E-Journal Program Pascasarjana Universitas Pendidikan Ganesha, $4(1)$.

Trianto. (2012). Model Pembelajaran Terpadu. Jakarta: Pt. Bumi Aksara.

Utami, R. D., Agung, S., \& Bahriah, E. S. (2017). Analisis Pengaruh Gender Terhadap Miskonsepsi Siswa Sman Di Kota Depok Dengan Menggunakan Tes Diagnostik TwoTier. Prosiding Seminar Nasional Pendidikan Fkip Untirta 2017, 93102.

Yuliati, Y. (2017). Miskonsepsi Siswa Pada Pembelajaran Ipa Serta Remediasinya. Jurnal Bio Educatio, 2(2), 50-58. 
Desimal, 2 (3), 2019 - 269

Ernawati, Siska Andriani, Farida, Bambang Sri Anggoro

Zulvita, R., Halim, A., \& Elisa. (2017).

Identifikasi Dan Remediasi

Miskonsepsi Konsep Hukum

Newton Dengan Menggunakan

Metode Eksperimen Di Man

Darussalam. Jurnal Ilmiah

Mahasiswa (Jim) Pendidikan Fisika,

2(1), 128-134. 